\title{
Cross-Border Crime and Its Security Concerns in Nepal
}

\author{
Dipesh Kumar K.C., PhD \\ Lecturer, Criminology, National Law College, Kathmandu \\ Senior Correspondent, Nagarik Daily \\ Email:dipeshkc@gmail.com
}

\begin{abstract}
The paper analyses the geopolitics of Nepal which significantly provide the opportunities for the crossborder crime enhancing the internal and external security threat to the country. It accounts various interest groups, overtly and covertly involved in the country, who have their vested interests play their role provide opportunities for the organised criminal groups. The paper interprets the secondary data, both qualitative and quantitative in nature, to interpret the topic. In conclusion, the paper highlights the supply and demand factor of Nepal, its neighbours and their geopolitics also affect the cross-border criminal activities in Nepal as well as via Nepal. The research finds the changing political and economic circumstances in the region and the geographical opportunities develop the abundant grounds for the organised criminal groups in Nepal.
\end{abstract}

Key Words: Borderline, organised crime, geopolitics, opportunities, security

\section{Introduction}

Cross-border crime is the illegal activities of individuals and organisation whose actions straddle territorial boundaries and whose objectives are to maximize economic profits or achieve political objectives (Lo, 2009, p. 3). In Indo-Nepal border areas, there is additional concern about the increment in crime, especially cross-border crime. The involvement of organised criminal gangs in drug, counterfeit, kidnapping and extortion with a nexus between the politicians and the criminal gangs have been accounted $(\mathrm{KC}, 2016)$. They significantly misused the people vulnerable to the crime.

Smuggling is quite prevalent in the border points all over the world but is organized in nature. The practice of smuggling of ordinary goods in the border areas has import or export taxes imposed that lead to the smuggling of contraband goods. Reckless (1967) outlined that smuggling is the main characteristic of international border crime (p. 117). He further highlights that smuggling in the borderline is the result of import or export duties on commodities and the national border seems to attract and make smugglers.

Millets (2007) defines border as significant for a homogeneous society and culture whereas it is marginalized from the central area, and thus criminal gangs can conduct criminal activities. Organized criminal groups can get local support due to vulnerability, both geographically and socially, and they misuse people for their vested interests. Conway (2002) argues the role of modern technology in enabling the cross-border crime. Technical innovation and its speed cross the border which also contributes to the spreading of criminal activities. Aas (2007) uses the term 'transnationalism'- changing the form of social relation that plays a vital role in changing the form of crime.

Cross-border crime is twenty-first century's booming illegitimate industry. According to Devetak (2008), goods, capital, people, information and principle beliefs, as well as arms, drugs, criminals, terrorists and pollutants, now appear to traverse nation-state borders with greater ease and speed and in larger volume than ever before. Thachuk (2007) mentions that smuggling and trafficking, now more than ever, are booming industries (p. 3). In this era of rapid globalization, the incentives for cross-border crime have increased, as criminals have identified the opportunities to gain greater rewards from criminal activity outside their traditional boundaries. Organized criminal groups have enhanced and extended their networks throughout the world, weakening borders of the nation-state. Illicit goods are smuggled and proliferated across the border in which the borders are misused or affected.

The geographical significance, the land between two powers India and China, of Nepal provide feasibility to the cross-border crime that also affects the internal security of the country. Legal and illegal goods flow through the land and air rout of Nepal which leads the country towards the bridge of criminal activities prior in between India and Nepal. The new forms of cross-border crimes are accounted which also enhance organized crime in Nepal. In several contexts, the motivation of the crime is not only limited to the monetary interest also to the political interest. 


\section{2 | Journal of APF Command and Staff College}

\section{Literature Review}

There are several notable works related to the socio-economic interrelationship on Indo-Nepal border society. Nayak (2011) explores the economic vulnerability of people due to unemployment in the Tarai region of Nepal. According to THRDA (2011) report, the unemployment in youth contributes to the increment of crime. ICG (2007) sketches the structural transformation of Tarai society from agriculture to industry based. IAFP (2008) reported the lack of opportunities among young in Tarai which is contributing to crime. IAFP (2007) explores the rising frustration of youth of Eastern Tarai of Nepal due to lack of educational and economic opportunities. Housden (2009) outlines Tarai as the most unstable and deeply troubled region of Nepal and specifically highlighting the pervasive lawlessness. He further adds that historic exclusion and limitation of choices and opportunities, lead marginalized groups to be involved in criminal activities. Miklian (2008) traces the limited state capacity, a porous border, easy access to weapons and financial incentives for criminality in Tarai. IAFP (2008) explores the motivation of youth towards criminal gangs due to lack of opportunities, are the target of criminal gangs who misused them in their vested interests. Regarding the situation of Africa, SEESAC (2003) outlines the relationship between limitation of opportunities and serious crimes ${ }^{1}$ which felicitates small arms trafficking across the border.

Sirseloudi (2004) conducted research of Sri-Lanka, sketches the role of arms conflict in motivating young towards related crimes. Stucky (2006) argues the political factors behind the increasing crime. THRDA (2011) explores the youth who abandon the armed faction in Terai join criminal activities. UNICEF (2009) reported the recruitment of children and teens in armed related activities in Tarai. It argues that the political factors are affecting the society, imposing a large number of vulnerable sections of social members towards crime. KC (2017a) argues that cross-border smuggling becomes a way of life for several people resided in the Indo-Nepal borderline. It shows that the geographical opportunity in the available social milieu motivates the people towards the crime. Various researches conducted in other parts of the world are a landmark to analyze and understand crime in the areas where war was fought and the situation was transitional. The political instability and volatile political nature of Tarai provide terrain for organized criminal groups to operate their activities in their vested interest.

A considerable quantity of research has been conducted in cross-border crime but limited research work has been conducted on geopolitical aspects. Meanwhile, less attention has been paid to the geographical significance of the border in influencing crime and in turn leads social challenges. As a result, no comprehensive finding appears to exist in case of Indo-Nepal cross-border crime. Despite the importance given to the challenges of cross-border crime, limited researchers have studied in the related topic.

\section{Methodology}

The researcher has applied the strategies based on document analysis, a qualitative research technique with an efficient and effective way of gathering secondary data. The document those published from 1936 to 2018 were reviewed and interpreted to analyze the title of the study. Those documents have provided information and broad coverage of data contributed to the contextualizing the research within its subject. Furthermore, it has pointed out the question raised around the topic of the impact of cross-border crime in the internal security of Nepal. The documents are public records, personal documents and physical evidence made accessible through the books, libraries, government offices, e-libraries and online search engine.

The researcher has collected the data from documents such as newspapers, official reports of Armed Police Force, Nepal Police, media and other independent reports, journals, research works and books related to the cross-border crime, security-related issues associated to Nepal-India and Nepal-China. The researcher utilizes the paper presented at the seminar, unpublished papers, newspapers' reports. The paper indicates the gap in the previous research work including the government and nongovernment data. It has analyzed the contributing factors of Indo-Nepal cross-border crime.

The study has included a detailed description of the cross-border crimes and their interlink to the security issues. The study addresses the broad range of issues regarding the title, including geographical

\footnotetext{
1 "Serious crime" shall mean conduct constituting an offence punishable by a maximum deprivation of liberty of at least four years or a more serious penalty. See: UN Convention Against Transnational Organized Crime. 2000. p. 1.
} 
characteristics of Nepal-India borderline and the interest groups active in the area. The study has considered strategies for ensuring credibility and considers ethical issues, e.g. confidential documents.

\section{Theoretical Perspectives}

\section{Environmental Aspects}

An environment is an important factor of crime, motivates social members towards crime. Though it provides opportunities to them, however, it may or may not motivate towards crime. Study based on environment known as environmental criminology is concerned with crime, not criminality (Wortley, 2008, p. 15). It looks for crime patterns and seeks to explain them in terms of environmental influences. Coleman (1989) argues environmental situations or cultural attitudes can change much more rapidly and therefore a learned disposition towards crime seems more likely (p. 109). Explaining society as the product of individuals' actions, actions that are enabled or constrained by society, Lee (1997) argues that human individuals both effect and are affected by their "environment" (p. 20). It also applies to crime because certain environment emphasizes or deemphasizes criminal acts. Skinner (1953) recognizes that criminal behaviour cannot occur without opportunity, which he saw as a necessary but not a sufficient condition for the crime.

An environment cannot be neglected because the given environment enforces social members towards crime. Environment motivates social members to act legally or illegally which depends upon opportunities and the capability to grab such opportunities.

\section{Geographical Aspects}

Geography is one of the important factors which influence criminal activities in the society. Park and Burgess (1936) studied the geographic locations of high crime rates rather than criminals and developed the notion that urban development is patterned socially and develops naturally in concentric zones (p. 1$15)$.

Brantingham (1981) arguing any crime consists of four dimensions of the law, the offender, the target, and the place (p. 4). The place is one of the important dimensions which provides appropriate conditions for crime, affects the social condition of people. Geography deals with social relations to direct attach and detach societies, also generate several social problems like crime. Geography as a factor influencing social structure can encourage crimes. Border as a geographical location segregates nation-state is the line which plays a role to determine the action of social members. It is further illustrated by Carter and Jones (1989) describing crime is to a significant degree the product of locality and not solely the character residents (p. 83).

Geography develops close social relation among cross-border people, who share positive and negative outcomes. Geography not only contributes to socio-cultural similarities across the border but also gives risk to similar social problems. Bondeson (2005) has noted that crime trends are very much the same in the Scandinavian countries, where a striking similarity between trends over the past fifty years. Despite developed welfare systems, these countries exhibit the same increasing trends for crimes. Geographically attached, India and Nepal have similar crime trends which are aroused due to similar social problems. The similarities of problem and crime are able to cross the border through various networks, getting an advantage due to socio-cultural interconnection. Geographical characteristics of Nepal, between huge and diverse societies like China and India, has deep effects on its social structure. Indo-Nepal cross-border crime can be understood by analysing the characteristics of the geography and socio-cultural, socioeconomic aspects as well as other external factors affecting the internal structure of the society. Nepal is situated at the heart of Asia and landlocked between two neighbours, India in the South and China in the North (Yadav, 1992, p. 28). On the basis of the explanation of geopolitics, scholars explain the sociopolitical situation. The people living near the borders of the north and south have easy access to the neighbouring countries for trade and social intercourse.

Eagle (1999) outlines that Nepal lies between two major civilisations (China and India) which are cultural, linguistically and racially distinct (pp. 272-327). Though the two big countries have dissimilarities, the edge of Southern Nepal has more geographical and socio-cultural similarities in comparison to another border of both nations. Nepal shares borders with five Indian states: the longest and most significant are with Bihar and Uttar Pradesh; there are also borders with Uttaranchal, West Bengal and Sikkim (ICG, 2007, p. 25). The researchers also highlighted the Indo-Nepal border regions as 


\section{4 | Journal of APF Command and Staff College}

a definite geographical region from the southern part of Nepal, called the Tarai, is extended from the Indian border to the bottom of the foothills rather than analyzing historical significance of socio-cultural similarities. Nepal India and China are facing the challenges of organized crime which has strong networks throughout the region. The Indo-Nepal border regions are highly affected, facing cross-border criminal activities, especially smuggling and small arms-related crimes. The Tarai is engulfed in a perfect storm of limited state capacity, a porous international border, easy access to weapons, financial incentives for criminality, and violent actors (Miklian, 2008, p. 2).

Balibar (2002) argues about the border as a key geographical concept at the centre of the politics of mobility, identity, and economy. These three terms are directly interlinked with the social setting which is deeply structured across the border societies. Borders are also a means and symbol of place-making (Houtum, 2010, p. 37-58). Chiara (2009) argues that borders are socio-political discursive constructions where symbolic, historical, and religious values are shared by social communities (pp. 582-88). The shared values by the close attachment make them structured as one society, interrelating socially, politically and economically. Some people nearby border always try to make free flow, maintain a unique identity and do their best to get benefit from the economic activity happen from the border areas. People in the Indo-Nepal border are geographically attached which has also been at the centre of the politics of mobility, identity and economy. In the border areas like Indo-Nepal, society social practices are common rather than shared. India and Nepal shared a long border, opened and porous, in which people in edges have a similar culture. By virtue, geographical attachment and similarities in border regions are beneficiaries for free flow and cross-nation contact, but it is also providing advantages to criminals. Definite society in the border areas are highly interactive with each other, meanwhile, there is an impact of changes in other parts of the world. In brief, globalization has affected the border where societies of the two nations are in a close tie and economic as well as political activities are growing due to the rapid speed of technology and communication.

Lakshman and Jha (2001) argue that the ethno-cultural proximity of Indo-Bangladesh populations on both sides of the borders, and the absence of physical barriers and vigilance by security forces have facilitated illegal border trade. Despite tight border security and fencing, socio-cultural affinity is capable to demolish the enforced law and physical barriers set up by nations. Cross-cultural closeness has such a capacity that they can challenge the imposed law and order, thus crime occurs in the form of cross-border crime. Laxman and Jha (2001) further mention that the success of the fencing experience in Punjab, IndoPak border, influenced the government's decision to fence the entire India-Bangladesh border. Crime in the border area is organized in nature due to economic reasons.

\section{Affinities Provide Opportunities}

Societies on both sides of the Indo-Nepal border areas have similar identities and social structure. The society of the border is taken seriously for reasons of security but overlooked in social understanding. This approach has seeds that can lead to problem and challenges in politically segregated areas even though they are socially and culturally similar. Whenever the question of cross-border crime is raised, it becomes more intriguing given the tight security in the border areas.

Cross-border crime is related to transnational activities and organized network of different groups across the border, link up each other and contribute to flourishing transnational organized crime (KC, 2013a, $\mathrm{p}$. 59). Transnational organized crime is a phenomenon with multiple facets which has grown exponentially. Duyne (1996) argues that transnational crime should be understood as a more or less direct reflection of the prevailing international market relationships of supply and demand (p. 342). Meanwhile, the way of trafficking is modernized in terms of both supply and demand side. Vlaesis suggests (2000) organized criminal groups are extending their activities around the globe, and are engaging with an increased level of sophistication in a variety of activities that range from the tradition to the modern (p. 10). Border people are in vulnerable zone as they are attempted to motivate themselves towards crime. Criminal gangs try to access up to leadership level, particularly powerful political leaders, and ethnic leaders and then they make access to the people of the region and ethnic groups who are socially vulnerable, misused them in risky activities. Transnationalisation ${ }^{2}$ has the long history in terms of India and Nepal. The

\footnotetext{
2 Transnationalisation is a process by which inter-governmental relations at an international level are supplemented by relations between non-governmental individuals and groups. See: Waters, M. (1995). Globalization. London: Routledge. p. 29.
} 
people of both the country have close social ties through marriage and family relations. The criminals of Indian border society can have a better understanding of the Nepalese side and vice versa which support them to handle their activities across the border. Meanwhile, they can hide in any side by crossing the border if they are unsafe from legal institutions (KC, 2013a, p. 63). Global production, technological changes and vibrant communication enhance transnational organized crime which specifically carried out crime by organized crime organization, thus provide better strength to cross-border criminals who are active in Indo-Nepal border areas who have already the advantage of socio-cultural similarities across the border.

Several cross-border crimes, such as human trafficking, drugs trafficking have a direct effect on the country's youth population. The country is continuously losing the youth population of the country. Traffic youth from Nepal to the third countries are rescued in Indian cities. On the other hand, organized criminal groups are misusing Nepal's land which is accounted in the case of counterfeit notes. Meanwhile, internal instability of the country makes better terrain in the country for organized criminal.

\section{Challenges in Indo-Nepal Borderline}

Regarding the dimension of crime at the political border in Indo-Nepal border areas, it is not unique, since border crime has long existed throughout the world. The Indo-Nepal border faces crime related to national boundaries on the political borders. Das (2008) interprets the disadvantages of Indo-Nepal open border system which provide the opportunities for smugglers, drug and arms traffickers, terrorist and insurgents, petty criminals, etc. According to Watson and Crozier (2009), the open border between Nepal and India is perceived to be a key contributing factor to the high levels of crime in the Terai regions (p. 15). According to Shrestha (2017), the open border has more or less disturbed the security system of Nepal and India and at present context, challenges are growing from outside Nepal (p. 264).

Blaming the characteristics of border such as geographical viability, people, culture, cross-border contact and borderless nature is a way of stereotyping the region as a crime zone. Braun (2010) concludes that a porous border is one of the causes of cocaine trafficking in West Africa (p. 4). Lo (2009) regards the borderless nature of the entire Greater China regions is the prominent factor shaping the incessant crossborder crime (p. 187). Upreti (2010) describes the cross-border connection of criminals in Indo-Nepal border areas (p. 249-50). It may not be obvious that the adjoined border area is unsafe due to the terrible crime rates on the other side. Despite the border adjoined with the city of Mexico, world's dangerous place, in terms of crime rates, El Parlo city of Texas is ranked among one of the safest cities in America. Shashikumar (2008) states that Nepal-Bihar border is largely unmarked, unguarded and highly porous, where cross-border smuggling is out of control. McDonald and Vaughn (2013) outline India-Nepal border as a porous. Baral and Pyakurel (2013) urge India-Nepal border as an "open border" not "porous border". KC (2013a) has challenged the trends of biased arguments which blame open border as a prime cause and further developed the concept that open border with India is not the prime cause of Indo-Nepal cross-border crime and dismiss the presumption that the open border is possibly leading (p. 86).

The supply and demand context play vital role on cross-border criminal activities. Research conducted by the Department of Custom in 2007 shows that average daily two ways flow of the people across IndiaNepal is 13283 whereas daily smuggling legal/illegal cost NRs. 44600 000. It has estimated that annual stolen and smuggled materials cost thirteen billion eighty-one crores rupees (NRs 13,810,000,000). ${ }^{3}$ The context shows Nepal and the demand side and India as the supply side of the goods illegally smuggled through the land route. On the other hand, illegal goods smuggle in both the sides depending on their market and opportunities for vested interests.

\section{Organized Crime in Border Areas}

Major types of Crime

- Drugs

- Human

- Small-Arms

- CITES

\footnotetext{
${ }^{3}$ Department of Custom, Ministry of Finance, Nepal, on 26 January 2007 has published Annual Report indicated the estimation of the cost of the daily smuggling illegal/legal goods across the Indo-Nepal border. Also See: KC. 2013. Crime and Money in Nepal. Kathmandu: Brothers Books. pp.176-177.
} 
- Gold

- Counterfeit

- Kidnapping

Organized crime is more organized than the state (Nordstrom, 2004, p. 133). Organized crime strengthen their networks in Indo-Nepal border areas for operating drug cultivation and trafficking, gold smuggling, trafficking of counterfeit notes, human trafficking, CITES ${ }^{4}$ crimes (Wildlife crime), and smuggling of goods by illegal channels.

Global Financial Integrity report Nepal lost 8.7 billion US dollars due to a large-scale capital flight has taken place in between 2003-2012 (Kar \& Spanjers 2014, p. 44). In two different cases of capital flights, 1.5 million and 1.8 billion being siphoned off the country in 2009 and 2010 respectively (KC, 2013b, p. 86).

Criminal elements can infiltrate any political system by forging links with politicians and government officials (Lo, 2009, p. 6). Criminalization of politics is evident in more or less all over the world. On the other hand, increasing corruption is the major problem of Nepal. ${ }^{5}$ The bureaucracy in Nepal and India is highly susceptible to corruption that may ease the organized criminals to penetrate in local level to highlevel bureaucracy deploy in Nepal-India borderlands.

\section{Security Challenges}

The motives of cross-border Crime are:

- Economic

- Political

- Social

Nepal has faced several challenges of cross-border crime, interlink to the organized crime. The cases of smuggling of gold, illicit drugs, human trafficking, CITES crime, has been increased (See Table no. 1). Regarding the involvement of well organized criminal groups in such crime, it becomes a threat to the internal security of the country. Regarding the gold smuggling cases in Nepal, KC (2018) argues that Nepal has become a transit point for transporting illegal goods such as drugs, endangered species, gold and even human beings to other countries.

Table 1: Filed Cases of Organised and Economic Crimes in Nepal Police

\begin{tabular}{|l|l|}
\hline Fiscal Year & No. of Cases \\
\hline $2071 / 72$ & 3189 \\
\hline $2072 / 73$ & 3723 \\
\hline $2073 / 74$ & 3593 \\
\hline $2074 / 75$ & 4656 \\
\hline
\end{tabular}

Source: Nepal Police, 2018

The activities of fake currency racket have their vested interest. KC (2017b) argues that the proxy war between regional powers reflect in fake currency related activities in Nepal's Terai. It shows that the influence of external forces in cross-border organised crime. Similarly, smuggling of redsandalwood disclose the well-organised criminal groups actively involved in smuggling of illegal goods in between India and China making Nepal a bridge for their illegal activities.

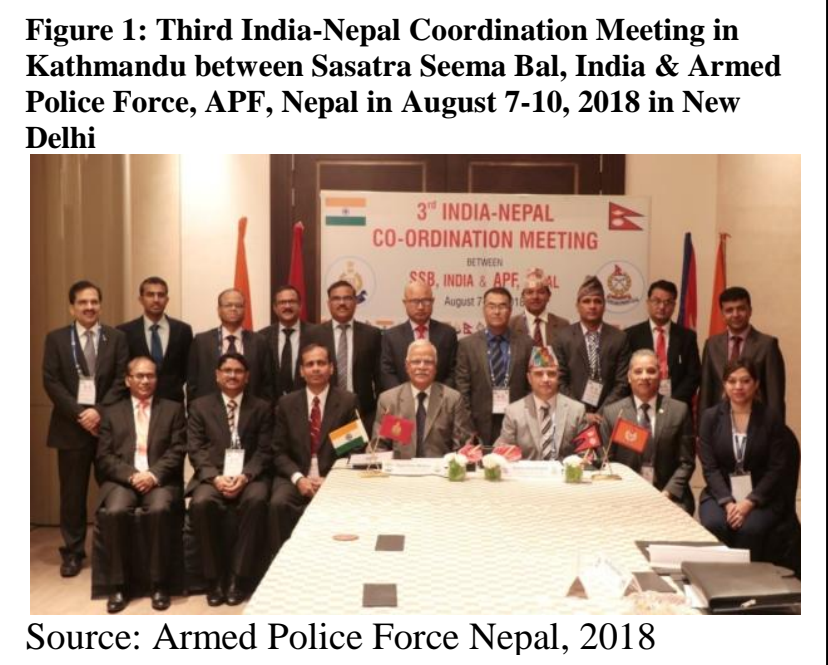

\footnotetext{
${ }^{4}$ Convention on International Trade in Endangered Species of Wild Fauna and Flora regulates exports, imports and reexports of wildlife.

${ }^{5}$ Corruption Perception Index (CPI) 2015, the survey released by the Berlin-based watchdog Transparency International, has placed Nepal in 130th position with a score of 27 among 167 surveyed countries indicates Nepal in a highly corrupt category. See: Beddow, Rachel, ed. 2016. Corruption Perceptions Index 2015. Berlin: Transparency International.
} 
Islamic Fundamentalist and the separatists are active in the Indo-Nepal border areas. They have their vested-political interests. KC (2017c) mentions that several fundamentalists and separatists, Yasin Bhatkal, Tunda, Niranjan Hojai, etc., active against India were arrested in Nepal (p. 77). Hence, transborder crime sometimes may have a link with terrorism. Regarding the arrestment of Niranjan Hojai, leader of India's separatist group, in Kathmandu, his interlink to the money laundering has been accounted (KC, 2013c, p. 68). The arrestment of Indian fugitives and members of terrorist groups in Nepal's land shows that they are creating an internal security threat to the country. According to Baral (2018), cross-border crimes and terrorism create tension between Nepal and India. India always proposed mutual cooperation to tackle such problems. However, Nepal has proved that it is not a safe place for organised criminals and terrorist groups (KC, 2017c, p. 17).

The security forces have their grave concern on the activities of the separatist, both violent and nonviolent, in Terai. Baral and Shah (2018) mention that armed groups based on the Terai with separatist outlook are launching violent activities. The transnational organized criminal groups misuse such outfits to accomplish their vested interests. The members of such groups are vulnerable to crime and likely a threat to the internal security.

\section{Governmental Intervention}

The two countries have deployed the border police to guard the border-line; moreover, other security forces are also active formally and informally. India has deployed Border Patrol Force [Seema Surakshya Bal (SSB)] on the entire Nepal-India borders establishing her armed posts in about three kilometres gap whereas Nepal has deployed Armed Police Force setting her posts in between 15-20 kilometres gap (Baral \& Pyakurel, 2013, p. 6). The aims of both armed police forces are to stop smuggling, prevention of criminals from passing the border, and prevention of girls trafficking, the transaction of fake currencies, arms and amenities and security of customs checkpoints. Despite the increments of the number of the border force in the borderline and tightening the regulation procedures at the checkpoints, smuggling as well as illegal cross-border trade has increased. On the other hand, informal extradition of criminals, who run and hide on the other side of the border, has been practised. However, the results of the regulation and the extradition have not found to be efficient than its prediction to combat cross-border crime.

Table 2: Armed Police Force, Nepal's Deployment along Nepal China Border

\begin{tabular}{|c|c|c|c|}
\hline S.N. & Province & $\begin{array}{c}\text { No. of } \\
\text { Company }\end{array}$ & Remarks \\
\hline 1. & 1 & 3 & \multirow{6}{*}{$\begin{array}{l}1 \text { Company = } \\
160 \mathrm{APF} \\
\text { personnel }\end{array}$} \\
\hline 2. & 3 & 4 & \\
\hline 3. & Gandaki & 3 & \\
\hline 4. & Karnali & 3 & \\
\hline 5. & Sudur Paschim & 2 & \\
\hline & Total & 15 & \\
\hline
\end{tabular}

Table 3: Number of Border out Posts of APF, Nepal along Indo-Nepal Border

\begin{tabular}{|c|c|c|c|}
\hline S.N. & Province & $\begin{array}{l}\text { No of } \\
\text { BOPs }\end{array}$ & Remarks \\
\hline 1. & 1 & 17 & \multirow{6}{*}{$\begin{array}{c}1 \mathrm{BOP}=35 \mathrm{APF} \\
\text { personnel }\end{array}$} \\
\hline 2. & 2 & 49 & \\
\hline 3. & 3 & 3 & \\
\hline 5. & 5 & 17 & \\
\hline 6. & Sudur Paschim & 5 & \\
\hline & Total & 91 & \\
\hline
\end{tabular}

The characteristics of the Indo-Nepal borderline and borderlands has rapid changing dynamics (KC, 2017d, p. 168). The government has increased the security budget to curb the crime rather than social development. Till 2014, the Nepalese government had established 21 Armed Police Force (APF) border security offices and 48 border outposts to tackle cross-border crime (KC, 2016, p. 48). In view of checking possible infiltration of criminal elements and curbing cross-border crimes, Nepal has prepared to strengthen security presence along its international border with India and China. According to APF, there are a total of 91 BOPs along the border with India and 15 companies in along the border with China (Table No. $2 \& 3$ ). The government plans to increase the number of BOPs to around 125 along the border with India and additional 12 BOPs along the Chinese border in the north. Currently, there are only two APF outposts - Tatopani and Rasuwagadhi. The number of BOPs will be increased in each of these districts based on security sensitivity. APF, Nepal is planning to set up 200 BOPs along International Border in the next two years. Also, it has launched operations in Terai to curb the small arms and related crimes. APF conducted a joint operation with Nepal police in Terai region beside it has done the single-handed 


\section{8 | Journal of APF Command and Staff College}

operation to curb small arms-related crime. ${ }^{6}$ Further, it has prioritized surprise checkpoints and vigorous mobile as well as foot patrols.

According to KC (2018), the organised crime organisations and their activities create further threats to the security of the South Asian region which, in turn, fuels terrorist groups. Hence, Nepal alone cannot solve the problem of such crimes. However, Nepal implements the plan and policies based on the strengthening of security forces.

Regarding the investment in border security and deployment of security force along Nepal-India border and Nepal-China border, APF has seized immense illegal goods through the borderline. In 2074/75, the APF seized goods of estimated price of 250 million (See: Table No. 4). However, the seized goods are nominal in comparison to the real figure of smuggled goods through the borderline of Nepal. In Fiscal Year 2074/75, Nepal Police has seized $178 \mathrm{~kg}$, estimated price of NPR 890 million, gold smuggled in the country which is generally smuggled towards India (See Table No. 5). The increasing numbers of organised crime cases filed in the police also reflects the magnitude of crime in the borderline. Despite the tight security and increment of the deployment of the security force, the cross-border crime

Table 4: Seizure of Goods, Weapons, Illegal Drugs Etc. In Borderline by APF

\begin{tabular}{|c|c|}
\hline Fiscal Year & $\begin{array}{c}\text { Estimated cost of } \\
\text { Confiscated Goods (NRs.) }\end{array}$ \\
\hline $2074 / 75$ & $25,00,00,000$ \\
\hline $2075 / 76$ (Till Kartik) & $6,00,00,000$ \\
\hline
\end{tabular}

Source: Armed Police Force Nepal, 2018

Table 5: Seized Smuggled Gold in Nepal

\begin{tabular}{|c|c|}
\hline Fiscal Year & Seized Gold $(\mathbf{k g})$ \\
\hline $2071 / 72$ & 111.44 \\
\hline $2072 / 73$ & 68.50 \\
\hline $2073 / 74$ & 91.38 \\
\hline $2074 / 75$ & 178.12 \\
\hline
\end{tabular}

Source: Nepal Police, 2018 is increasing. Hence, increasing the deployment of the security force is not the ultimate solution. While tightening the security and increment of the deployment of the security force, the government has to focus on various sectors that affect the cross-border crime.

\section{Conclusion}

Nepal, the land between two economically and politically powerful nations: India and China, has the geographical significance which provides feasibility to the cross-border crime that also affects the internal security of the country. Legal and illegal goods and money flow through the land and air route of Nepal which leads the country towards the bridge of criminal activities prior in between India and Nepal. Various forms of cross-border crimes enhancing organized crime in Nepal are accounted. In several contexts, the motivation of the crime is not only limited to the monetary interest but also to the political interest. Nepal India and China are facing the challenges of organized crime which has strong networks throughout the region. The Indo-Nepal border regions are highly affected, facing cross-border criminal activities, especially smuggling and small arms-related crimes.

The supply and demand context plays a vital role in cross-border criminal activities. The context shows Nepal as the demand side and India as the supply side of the goods illegally smuggled through the land route for most of the smuggled goods. On the other hand, illegal goods smuggle in both the sides depending on their market and opportunities for vested interests. The changing political and economic circumstance in the region, as well as the geographical opportunities, develops the fertile grounds for the organized criminal groups in Nepal.

Organized cross-border crimes become a threat to the internal security of the country. In several contexts of cross-border crime, the crime operator misuses Nepal's land as a transit point for transporting illegal goods such as drugs, endangered species, gold and even human beings to neighbour countries as well as third countries. Organized criminals have been misusing Nepal as a bridge between India and China for their illegal activities.

Illegal ultra-forces and the separatists are active in the Indo-Nepal border areas. They have vestedpolitical interests with their association to the organized criminal groups. The increasing numbers or organized crime cases filed in the police stations also reflect the magnitude of crime in the borderline. The government implements the policy of tightening security and increment of the deployment of the

\footnotetext{
${ }^{6}$ Armed Police Force.Presentationon Illicit Use of Small Arms in Nepal. Retrieved December 11, 2018, from http://www.unrcpd.org.np/uploads/conferences/file/Illicit\%20Use\%20of\%20Small\%20Arms\%20in\%20Nepal,\%20Mr.\% 20Guna\%20Khar\%20Khanal,\%20Amred\%20Police\%20Force.pdf.
} 
security force. In spite of such policies, the cross-border crime is increasing that shows the deployment of the security force is not an ultimate solution.

Transnational interrelationship and movement are playing a role of a catalyst in the world which also leads criminal activities throughout the world. Border, whether they are open or closed are more or less porous due to organized crime rooted around the world, especially in the border regions. Combating cross-border crime is a tough task because of strong networks among smugglers, political leaders, security personnel, bureaucrats and gangsters. Interestingly, the new forms of technology are beneficial for organized criminals. Such rackets operate their activities in such a way that they do not need borderland. Regarding the cross-border criminal activities in Nepal's frontiers, new challenges are evolving. Hence, Security is the prime field of concerning issues. Security cannot be overlooked in the name of economic development and temporary prosperity. On the other hand, internal security is essential for the economic growth of a nation. Unless and until the border is safe and strengthen Nepal cannot gain its prosperity.

\section{References}

Aas, K.F. (2007). Analysing a world in motion: Global flows meet 'Criminology of the Other'. Theoretical Criminology, 11 (2), 283-303.

Balibar, E. (2002). Politics of the other scene. London: Verso.2004. We, the People of Europe: Reflections on Transnational Citizenship. Princeton, NJ: Princeton University Press.

Baral, B. N. (2018). Changing dynamics of Nepalese foreign policy: Patterns and trends. Journal of Political Science, 18, 25-45.

Baral, L.R. \& Pyakurel, U. (2013). India-Nepal open border: A field-based study on problems and prospects. Kathmandu: BP Koirala India-Nepal Foundation.

Baral, U.N. \& Sahh, A. (2018). National security of Nepal: Threats, challenges and solutions. International Journal of Humanities and Social Sciences, 1 (1), 1-11.

Bondeson, U. V. (2005). Crime and criminals in Nordic Countries. Society, 42 (2), $62-70$.

Brantingham, P. \& Brantingham, P. (1981). Environmental criminology. Beverly Hills: Sage.

Braun, M.A. (2010). Statement of Michael A. Braun, before the subcommittee on African affairs-"confronting drug trafficking in West Africa." In P. E. Daniels (Eds.), Africa's connection to the drug trade (pp.18). New York: Nova Science Publishers.

Carter, J. \& Jones, T. (1989). Social geography: An introduction to contemporary issue. Banglore: Arnold Publishers

Chiara, B. (2009). Borders: Paradoxical structures between essentialization and creativity. World Futures, 65 (8), 582-588.

Coleman, A. (1989). Disposition and situation: Two sides of the same crime. In Evans, J. \& Herbert T.D. (Eds.), The Geography of Crime (pp. 108-134). London: Routledge.

Conway, D. \& Wolfel, R. (2006). Geopolitical globalization: From world systems to global city systems. In Conway, D. \& Heynen, N. (Eds.), Globalization Contradictions: Geographies of Discipline, Destruction and Transformation (pp. 109-126). London: Routledge.

Das, P. (2008). Towards a regulated Indo-Nepal border. Strategic Analysis, 32 (5), 879-900.

Devetak, R. (2008). The globalization of political violence: Globalization's shadow. In Devetak, R. \& Christopher, W. H. (Eds.). London: Routledge.

Duyne, P.C.V. (1996). The phantom and threat of organized crime. Crime Law and Social Change, 24, 314377.

Eagle, S. (1999). The language situation in Nepal. Journal of Multilingual and Multicultural Development, 20 (4-5), 272-327.

Housden, O. (2009). Nepal: A failing state or a state in transition?. Research Paper, February. New Delhi: Institute of Peace and Conflict Studies.

Houtum, H. V. (2010). Borders of comfort: Spatial economic bordering processes in and by the European Union. Regional and Federal Studies, 12 (4), 37-58.

IAFP (International Alert and Friends for Peace). (2008). Youth perspectives on community security in the Eastern Terai youth perspectives on community security in the Eastern Terai. Kathmandu: International Alert. 


\section{0 | Journal of APF Command and Staff College}

IAFP (International Alert and Friends for Peace). (2007). Youth speak out on community security in the Eastern Terai. Kathmandu: International Alert.

International Crisis Group. (2007). Nepal's troubled Tarai region. Kathmandu: ICG. Asia report No.136, July 9, 2007.

Kar, D. \& Spanjers, J. (2014). Illicit financial flows from developing countries: 2003-2012. Washington: GFI (Global Financial Integrity).

KC, D. (2013a). Social causes of Indo-Nepal cross-border crime. Kathmandu: Brother Books.

KC, D. (2013b). Crime and money in Nepal. Kathmandu: Brother Books.

KC, D. (2018, April 18). Busting smuggling racket. My Republica, p. 7.

KC, D.K. (2013a). Social causes of Indo-Nepal cross-border crime. Kathmandu: Brother Books.

KC, D.K. (2013b), Crime and money in Nepal. Kathmandu: Brother Books.

KC, D.K. (2013c), Nepal ma sangathit aparadh (Organized crime in Nepal) . Kathmandu: Brother Books.

KC, D.K. (2016). Youth in Indo-Nepal 'cross-border' crime (Doctoral dissertation). Jawaharlal Nehru University, New Delhi.

KC, D.K. (2017a). Labeled or learned? Youth in Indo-Nepal cross-border crime. Dhaulagiri Journal of Sociology And Anthropology, 11, 164-183.

KC, D.K. (2017b). Fake currency racket in Nepal's Terai. Journal of Money Laundering Control, 20 (3), 262273.

KC, D.K. (2017c). Bharat-Nepal relations: Defense and security issues. In Poudel, T. \& Adhikari, D.K. (Eds.), (pp.77-80). Kathmandu: Neeti Anusandhan Pratisthan, Nepal.

KC, D.K.(2017d). Nepal-Bharat relations: Economic development and cooperation. In Poudel, T. \& Adhikari, D.K. (Eds.), (pp.167-169). Kathmandu: Neeti Anusandhan Pratisthan, Nepal.

Lakshman, K. \& Jha S. K. (2001). India-Bangladesh: Restoring sovereignty on neglected borders. SATP (South Asia terrorism portal) and Institute for Conflict Management. Retreived December 10, 2018, from http://www.satp.org/satporgtp/publication/faultlines/volume14/Article7.htm.

Lee, M.E. (1997). From enlightenment to chaos toward non modern social theory. In Eve, R.A., Horsfall, S. \& Lee, M.E. (Eds.), Chaos, Complexity, and Sociology: Myths, Models and Theories (pp. 15-29). London: Sage.

Lo, S. H. (2009). The politics of cross-border crime in Greater China: Case studies of Mainland China, Hongkong and Macao. New York: An East Gate Book.

Miklian, J. (2008). Nepal's Tarai: Constructing an ethnic conflict. South Asia Briefing Paper 1. Oslo: International Peace Research Institute.

Millett, R. L. (2007). Weak states and porous borders: Smuggling along the Andean Ridge. In Thachuk, K. L. (Ed.), Transnational Threats: Smuggling and Trafficking in Arms, Drugs and Human Life (pp. 164176). London: Praeger Security International.

Nayak, N. (2011). The Madhesi movement in Nepal: Implications for India. Strategic Analysis, 35 (4), 640660.

Nordstrom, C. (2004). Shadows of war: Violence, power, and international profiteering in the twenty-first century. London: University of California.

Park, R. E. \& Burgess, R. (1936). Human ecology. American Journal of Sociology, 42, 1-15.

Parthasarathy, G. (2016). Nepal and India: Exploring new vistas. In Adhikari, D.K. \& Paudyal, M. (Eds.), (pp.134-138). Kathmandu: Neeti Anusandhan Pratisthan, Nepal.

SEESAC (The South Eastern and Eastern Europe clearinghouse for the control of small arms and light weapons). (2003). Cross border trafficking in South Eastern Europe: Assessing trafficking activities in the Southern Adriatic region, October 18, 2003, 13-14.

Shashikumar V. K. (2008) Pakistan's export of fake currency via Nepal. Indian Defence Review, 23 (4). Retrieved December 15, 2018, from http://www.indiandefencereview.com/interviews/pakistansexport-offake- currency-via-nepal/.

Shrestha, B.N. (2017). Border management of Nepal and security concern. In Poudel, T. \& Adhikari, D.K. (Eds.), Bharat-Nepal relations: Defense and Security Issues. (pp.261-272). Kathmandu: Neeti Anusandhan Pratisthan, Nepal.

Sirseloudi, M. P. (2004). Early detection of Terrorist campaigns. In Schmid, A.P. (Ed.), United Nations Office on Drugs and Crime: Forum on crime and society, $4(1 \& 2)$. 
Skinner, B.F. (1953). Science and human behaviour. New York: Macmillan.

Stucky, T. D. (2006). Local politics and violent crime in U.S. cities. In Rosenfield R. (Ed.), Crime and Social Institutions (pp. 351-385). England: Ashgate.

Thachuk, K.L. (2007). Transnational threats: Smuggling \& trafficking in arms, drugs \& human life. London: Praeger Security International.

THRDA (Terai Human Rights Defenders Alliance). (2011, July). Small arms terror in Central Madhes. Report July 2011.

UNICEF. (2009). Assessment of child protection concerns of children in Terai Districts. Kathmandu: UNICEF.

Upreti, B. R. (2010). Proliferation of small arms and challenges to post-conflict state building. In Upreti B.R., Sharma, S.R., Pyakurel, K.N. \& Ghimire, S. (Eds.), The Remake of a State: Post-Conflict Challenges and State Building in Nepal (pp. 241-257). Kathmandu: Kathmandu University.

Vlaesis, D. (2000). Cross border crime: Long arm of the law. World Today, 56 (12) December, 10-11.

Watson, C. \& Crozier, R. (2009). Security for whom? security sector reform and public security in Nepal. Brussels: International Alert.

Wortley, R. (2008). Situational precipitators of crime. In Wortley, R. \& Mazerolle, L. (Eds.), Environmental Criminology and Crime Analysis (pp. 48-69). UK: Willan Publishing.

Yadav, S. R. (1992). Rural and agrarian social structure of Nepal. New Delhi: Common Wealth Publishers. 